Original article

\title{
ASSOCIATIONS BETWEEN NEWLY DISCOVERED POLYMORPHISMS OF THE MYDI GENE AND BODY PARAMETERS IN STAVROPOL BREED RAMS
}

\author{
V. TRUKHACHEV, V. SKRIPKIN, E. TELEGINA, O. YATSYK, \\ N. GOLOVANOVA \& A. KRIVORUCHKO
}

Faculty of Veterinary Medicine, Stavropol State Agrarian University, Stavropol, Russian Federation

\section{Summary}

Trukhachev, V., V. Skripkin, E. Telegina, O. Yatsyk, N. Golovanova \& A. Krivoruchko, 2018. Associations between newly discovered polymorphisms of the MyoD1 gene and body parameters in Stavropol breed rams. Bulg. J. Vet. Med., 21, No 1, 28-39.

The aim of this study was to investigate the influence of the MyoDl gene polymorphisms on some body parameters in sheep. MyoDl polymorphisms were detected using NimbleGen sequencing technology (Roche, USA). The effect of polymorphisms identified was investigated in Stavropol sheep breed rams $(n=30)$. In coding and regulatory parts of gene 26 , single nucleotide polymorphisms (SNP) were detected. These were the substitutions: c. $-2112 \mathrm{C}>\mathrm{G}$, c. $-1806 \mathrm{~A}>\mathrm{G}$, c. $-1687 \mathrm{~T}>\mathrm{C}$, c.$1608 \mathrm{C}>\mathrm{T}$, c. $-1603 \mathrm{G}>\mathrm{T}$, c. $-1578 \mathrm{G}>\mathrm{A}$, c. $-1235 \mathrm{G}>\mathrm{A}$, c. $-910 \mathrm{G}>\mathrm{T}$, c. $-909 \mathrm{G}>\mathrm{T}$, c. $-880 \mathrm{G}>\mathrm{A}$, c. $-637 \mathrm{C}>\mathrm{T}$, c. $-412 \mathrm{G}>\mathrm{T}, \quad$ c. $244 \mathrm{C}>\mathrm{T}, \quad$ c. $246 \mathrm{G}>\mathrm{T}, \quad$ c. $253 \mathrm{G}>\mathrm{T}, \quad$ c. $259 \mathrm{G}>\mathrm{C}, \quad$ c. $261 \mathrm{C}>\mathrm{T}, \quad$ c. $269 \mathrm{C}>\mathrm{G}, \quad$ c. $274 \mathrm{C}>\mathrm{A}$, c. $276 \mathrm{C}>$ G, c. $277 \mathrm{C}>$ A, c. $279 \mathrm{C}>\mathrm{T}$, c. $281 \mathrm{C}>$ A, c. $287 \mathrm{C}>$ A, c. $325 \mathrm{~T}>\mathrm{C}$ and c. $483 \mathrm{C}>\mathrm{T}$. Sixteen of these SNPs have been identified for the first time. The complex of the four SNPs c.-1578, c.-880, c.-637, c.325 and c.-1235 occurred in Stavropol sheep breed only together. The study of the influence of these SNPs on the body parameters of rams showed the absence of significant correlation between their presence and the body size of the animals. The SNPs c.-910 and c.-909 were associated with improved body parameters, but they were found in a very small numbers of animals, which does not allow making definitive conclusions.

Key words: $M y o D 1$, sequencing, sheep, SNP, Stavropol breed

\section{INTRODUCTION}

A modern and promising method for prediction of breeding value and productive potential of animals is marker-assisted selection. It can be used in association with traditional selection methods to accelerate selection of animals with best production traits and reduce costs (Hagen et al., 2005).

The myostatin gene has a leading position among several genes related to meat quality of farm animals (Gan et al., 2008). However, often an increase in muscle mass is not associated with changes in the 
coding region of myostatin gene. Therefore, candidate genes that affect the myostatin gene function and muscle development in general have attracted more attention (Muroya et al., 2002; Hagen et al., 2005).

One of these genes is a member of the myogenic regulatory factors (MRF) genes family - MyoD1 gene (Busanello et al., 2012). Members of the MRF family are basic helix-loop-helix (bHLH) transcription factors. This family of genes also comprises Myf5, myogenin, and MRF4. (Buckingham, 1992). They play a key role in the differentiation and structure of skeletal muscle in vertebrates. The protein MyoD1 is capable to convert non-muscle cells, such as fibroblasts, into myoblasts that have the ability to fuse into myotubes (Davis et al., 1987). The MRF proteins contain several functionally distinct domains responsible for transcriptional activation, chromatin remodelling, DNA binding, nuclear localisation, and heterodimerisation (Tapscott et al., 1988; Weintraub et al., 1991; Vandromme et al., 1995; Gerber et al., 1997). The bHLH domain is highly conserved in all members of the family and allows for the formation of heterodimers that are bound to the E-box (CANNTG) locus. This locus is found in most of the regulatory regions of muscle-specific genes, including myostatin gene (Murre et al., 1989; Zhang et al., 2006).

It was previously shown that the MyoDl gene interacts with the promoter of the muscle specific creatine kinase gene (Huynen et al., 1992), and the myostatin gene (Du et al., 2007; Deng et al., 2012). In the regulation of postnatal myogenic programming of satellite muscle cells, the MyoD1 gene plays a critical role. Thus, mice with a knockout mutation in $M y o D 1$ gene have a severely reduced regenerative capacity after injury (Megeney et al., 1996). High levels of the MyoD protein inhibit the proliferation of satellite muscle cells and lead to either myogenic differentiation or apoptosis (Asakura et al., 2007; Pan et al., 2015).

A positive correlation between the level of expression of MyoD1 and the cold carcass yield was found in sheeps (Lobo et al., 2012). A polymorphism of MyoD1 gene in pigs is associated with meat quality (Klosowska et al., 2004; Kapelanski et al., 2005; Liu et al., 2008), including fatness (Kuryl et al., 2002) and meat marbling (Verner et al., 2007). In chickens, a mutation in both MyoDI and Mrf4 genes was associated with an increase in the diameter of muscle fibres. These genes are recommended as molecular markers for chicken marker-assisted selection (Yang et al., 2015). The effect of single nucleotide polymorphisms in $M y o D 1$ gene on the growth was examined in the Hanwoo breed of Korean cattle (Bhuiyan et al., 2009). In Chinese cattle breed, an influence of MyoDl gene polymorphism on meat quality traits was detected (Ujan et al., 2011). The relationship between mutations in MyoDl gene and indicators of meat quality in sheep has not been studied.

The Stavropol breed of sheep was bred in the period from 1921 to 1950 . The base for the creation of the Stavropol breed was Novokavkazskaya fine-fleeced sheep breed. During the breeding, American Rambouillet and Australian Merino rams were used. Among the wool breeds of sheep, the Stavropol breed is the biggest in size and has good meat productivity; it is well adapted to the climate of Stavropol territory. Nowadays, Stavropol breed is one of the largest fine-wool sheep breeds in Russia (Aboneev et al., 2011). It is also characterised by some good meat quali- 
ties, inherited from the original parental forms (Dmytryk \& Ovchinnikova, 2013).

The aim of research was to examine the structure of the gene MyoDl in the Stavropol breed of sheep and to identify polymorphisms associated with vital body conformation traits.

\section{MATERIALS AND METHODS}

\section{Sample collection}

The investigation was carried out on randomly selected one-year-old Stavropol breed rams $(n=30)$ from a livestock-breeding farm in Stavropol Krai, Russian Federation. All animals were healthy, kept in optimal conditions and fed with a total mixed ration. Body measurement parameters were analyzed in order to describe meat production.

\section{DNA isolation}

Genomic DNA was extracted from blood samples obtained from the jugular vein under aseptic conditions. Blood samples were collected in Vacutainer ${ }^{\circledR}$ vials with stabiliser EDTA (Becton Dickinson and Company, Franklin Lakes, NJ, USA) and were transported to the laboratory at $+4{ }^{\circ} \mathrm{C}$ within 6 hours. DNA was extracted from $0.2 \mathrm{~mL}$ of blood using the PureLink Genomic DNA MiniKit (Invitrogen Life Technologies, Grand Island, NY, USA).

Targeted enrichment and next generation sequencing

In order to detect mutations in the genes, targeted enrichment was done and the investigated DNA fragments were sequenced. For enrichment of target regions, we used NimbleGen technology (Roche NimbleGen, Inc., Madison, WI, USA). Probes for target regions were developed in cooperation with Roche NimbleGen (USA).
Libraries of DNA fragments were prepared in accordance with the protocol in the Rapid Library Preparation Method Manual undergoing the procedure of enrichment using NimbleGen SeqCap EZ Developer Libraries (Roche NimbleGen, Inc., Madison, WI, USA).

Monoclonal amplification of the enriched target regions of DNA was carried out according to a standard protocol in the emPCR Amplification Method Manual, Lib-L (Roche NimbleGen, Inc., USA).

Sequencing was performed using a GS Junior genomic sequencer (Roche NimbleGen, Inc., Madison, USA). The resulting sequences were mapped to the reference genome assembly Ovis aries oviAri3 (The National Center for Biotechnology Information. Genome, 2012, Ovis aries [sheep], 2015) by GS Reference Mapper v2.9 software (Roche NimbleGen, Inc., Madison, USA).

To describe a single nucleotide polymorphism (SNP) the HGVS nomenclature (www.hgvs.org) based on transcript ENSOART00000027076 (Anonymous, 2016) was used.

\section{Statistical analysis}

Phylogenetic analysis was performed using Unipro UGENE 1.15.1 software (Unipro, Russia). For statistical analysis, we used Student's t-test in Excel for Windows statistical plug-in. Significant difference was detected at $\mathrm{P}<0.05$.

\section{RESULTS}

As a result of our work we found 26 SNPs in the coding and regulatory regions of the MyoD1 gene. Sixteen SNPs were detected for the first time; 10 were previously added to dbSNP NCBI database (Table 1).

Replacement identified only in a heterozygous variant accounted for $34 \%$ of all 
Table 1. The frequency of the MyoDl gene polymorphic alleles in Stavropol sheep breed

\begin{tabular}{|c|c|c|c|c|c|c|c|c|c|}
\hline No & $\begin{array}{l}\text { SNP name, HGVS } \\
\text { nomenclature }\end{array}$ & $\begin{array}{l}\text { Identifier in the } \\
\text { NCBI database }\end{array}$ & $\begin{array}{l}\text { Position } \\
\text { in contig }\end{array}$ & $\begin{array}{l}\text { Amino } \\
\text { acid }\end{array}$ & \multicolumn{2}{|c|}{ Allele } & \multicolumn{3}{|c|}{ Genotype } \\
\hline 1 & c. $-2112 \mathrm{C}>\mathrm{G}$ & rs 404884444 & 34373234 & - & $\begin{array}{c}\mathrm{G} \\
0.97\end{array}$ & $\begin{array}{c}\mathrm{C} \\
0.03\end{array}$ & $\begin{array}{l}\mathrm{GG} \\
0.93\end{array}$ & $\begin{array}{c}\mathrm{GC} \\
0.07\end{array}$ & $\begin{array}{l}\mathrm{CC} \\
0.00\end{array}$ \\
\hline 2 & c. $-1806 \mathrm{~A}>\mathrm{G}$ & rs 424553252 & 34372928 & - & $\begin{array}{c}\mathrm{T} \\
0.2\end{array}$ & $\begin{array}{c}\mathrm{C} \\
0.8\end{array}$ & $\begin{array}{c}\text { TT } \\
0.13 \\
\end{array}$ & $\begin{array}{c}\mathrm{TC} \\
0.13 \\
\end{array}$ & $\begin{array}{c}\mathrm{CC} \\
0.73 \\
\end{array}$ \\
\hline 3 & c. $-1687 \mathrm{~T}>\mathrm{C}$ & rs 406278149 & 34372809 & - & $\begin{array}{c}\mathrm{A} \\
0.3\end{array}$ & $\begin{array}{c}\mathrm{G} \\
0.7\end{array}$ & $\begin{array}{l}\mathrm{AA} \\
0.26\end{array}$ & $\begin{array}{l}\mathrm{AG} \\
0.07\end{array}$ & $\begin{array}{c}\mathrm{GG} \\
0.67\end{array}$ \\
\hline 4 & c. $-1608 \mathrm{C}>\mathrm{T}$ & Not in database & 34372730 & - & $\begin{array}{c}\mathrm{G} \\
0.07\end{array}$ & $\begin{array}{c}\mathrm{A} \\
0.93\end{array}$ & $\begin{array}{l}\mathrm{GG} \\
0.00\end{array}$ & $\begin{array}{l}\text { GA } \\
0.13\end{array}$ & $\begin{array}{l}\text { AA } \\
0.87\end{array}$ \\
\hline 5 & c. $-1603 \mathrm{G}>\mathrm{T}$ & Not in database & 34372725 & - & $\begin{array}{c}\mathrm{C} \\
0.07\end{array}$ & $\begin{array}{c}\mathrm{A} \\
0.93 \\
\end{array}$ & $\begin{array}{c}\mathrm{CC} \\
0.00\end{array}$ & $\begin{array}{l}\mathrm{CA} \\
0.13 \\
\end{array}$ & $\begin{array}{l}\text { AA } \\
0.87\end{array}$ \\
\hline 6 & c. $-1578 \mathrm{G}>\mathrm{A}$ & Not in database & 34372700 & - & $\begin{array}{c}\mathrm{C} \\
0.83\end{array}$ & $\begin{array}{c}\mathrm{T} \\
0.17\end{array}$ & $\begin{array}{c}\mathrm{CC} \\
0.67\end{array}$ & $\begin{array}{c}\text { CT } \\
0.33\end{array}$ & $\begin{array}{c}\text { TT } \\
0.00\end{array}$ \\
\hline 7 & c. $-1235 \mathrm{G}>\mathrm{A}$ & rs 412308724 & 34372357 & - & $\begin{array}{c}\mathrm{C} \\
0.6\end{array}$ & $\begin{array}{c}\mathrm{T} \\
0.4\end{array}$ & $\begin{array}{l}\mathrm{CC} \\
0.2\end{array}$ & $\begin{array}{l}\text { CT } \\
0.8\end{array}$ & $\begin{array}{l}\text { TT } \\
0.0\end{array}$ \\
\hline 8 & c. $-910 \mathrm{G}>\mathrm{T}$ & rs 591152513 & 34372032 & - & $\begin{array}{c}\mathrm{C} \\
0.9\end{array}$ & $\begin{array}{c}\mathrm{A} \\
0.1\end{array}$ & $\begin{array}{l}\mathrm{CC} \\
0.8\end{array}$ & $\begin{array}{l}\mathrm{CA} \\
0.2\end{array}$ & $\begin{array}{l}\text { AA } \\
0.0\end{array}$ \\
\hline 9 & c. $-909 \mathrm{G}>\mathrm{T}$ & rs 601707240 & 34372031 & - & $\begin{array}{c}\mathrm{C} \\
0.9\end{array}$ & $\begin{array}{c}\mathrm{A} \\
0.1\end{array}$ & $\begin{array}{l}\mathrm{CC} \\
0.8\end{array}$ & $\begin{array}{l}\text { CA } \\
0.2\end{array}$ & $\begin{array}{l}\text { AA } \\
0.0\end{array}$ \\
\hline 10 & c. $-880 \mathrm{G}>\mathrm{A}$ & rs 412662330 & 34372002 & - & $\begin{array}{c}\mathrm{C} \\
0.83\end{array}$ & $\begin{array}{c}\mathrm{T} \\
0.17\end{array}$ & $\begin{array}{c}\mathrm{CC} \\
0.67\end{array}$ & $\begin{array}{c}\mathrm{CT} \\
0.33\end{array}$ & $\begin{array}{c}\text { TT } \\
0.00\end{array}$ \\
\hline 11 & c. $-637 \mathrm{C}>\mathrm{T}$ & rs 409662616 & 34371759 & - & $\begin{array}{c}\mathrm{G} \\
0.83\end{array}$ & $\begin{array}{c}\mathrm{A} \\
0.17\end{array}$ & $\begin{array}{l}\mathrm{GG} \\
0.67\end{array}$ & $\begin{array}{l}\text { GA } \\
0.33\end{array}$ & $\begin{array}{l}\text { AA } \\
0.00\end{array}$ \\
\hline 12 & c. $-412 \mathrm{G}>\mathrm{T}$ & rs 420129038 & 34371534 & - & $\begin{array}{c}\mathrm{C} \\
0.933\end{array}$ & $\begin{array}{c}\mathrm{A} \\
0.067\end{array}$ & $\begin{array}{c}\mathrm{CC} \\
0.87\end{array}$ & $\begin{array}{l}\mathrm{CA} \\
0.13\end{array}$ & $\begin{array}{c}\text { AA } \\
0.0\end{array}$ \\
\hline 13 & c. $244 \mathrm{C}>\mathrm{T}$ & Not in database & 34370878 & $\mathrm{D} \backslash \mathrm{C}$ & $\begin{array}{c}\mathrm{G} \\
0.00\end{array}$ & $\begin{array}{c}\mathrm{A} \\
1.00\end{array}$ & $\begin{array}{c}\mathrm{GG} \\
0.00\end{array}$ & $\begin{array}{c}\text { GA } \\
0.00\end{array}$ & $\begin{array}{l}\text { AA } \\
1.00\end{array}$ \\
\hline 14 & c. $246 \mathrm{G}>\mathrm{T}$ & Not in database & 34370876 & $\mathrm{~K} \backslash \mathrm{C}$ & $\begin{array}{c}\mathrm{C} \\
0.00\end{array}$ & $\begin{array}{c}\mathrm{A} \\
1.00\end{array}$ & $\begin{array}{c}\mathrm{CC} \\
0.00\end{array}$ & $\begin{array}{c}\mathrm{CA} \\
0.00\end{array}$ & $\begin{array}{l}\mathrm{AA} \\
1.00\end{array}$ \\
\hline 15 & c. $253 \mathrm{G}>\mathrm{T}$ & Not in database & 34370869 & $\mathrm{G} \backslash \mathrm{C}$ & $\begin{array}{c}\mathrm{C} \\
0.03\end{array}$ & $\begin{array}{c}\mathrm{A} \\
0.97\end{array}$ & $\begin{array}{c}\mathrm{CC} \\
0.00\end{array}$ & $\begin{array}{c}\text { CA } \\
0.07\end{array}$ & $\begin{array}{c}\text { AA } \\
0.93\end{array}$ \\
\hline 16 & c. $259 \mathrm{G}>\mathrm{C}$ & Not in database & 34370863 & $G \backslash \mathbf{P}$ & $\begin{array}{c}\mathrm{C} \\
0.00\end{array}$ & $\begin{array}{c}\mathrm{G} \\
1.00\end{array}$ & $\begin{array}{c}\mathrm{CC} \\
0.00\end{array}$ & $\begin{array}{c}\mathrm{CG} \\
0.00\end{array}$ & $\begin{array}{c}\mathrm{GG} \\
1.00\end{array}$ \\
\hline 17 & c. $261 \mathrm{C}>\mathrm{T}$ & Not in database & 34370861 & $G \mid R$ & $\begin{array}{c}\mathrm{G} \\
0.00\end{array}$ & $\begin{array}{c}\mathrm{A} \\
1.00\end{array}$ & $\begin{array}{c}\mathrm{GG} \\
0.00\end{array}$ & $\begin{array}{c}\text { GA } \\
0.00\end{array}$ & $\begin{array}{l}\text { AA } \\
1.00\end{array}$ \\
\hline 18 & c. $269 \mathrm{C}>\mathrm{G}$ & Not in database & 34370853 & $P \backslash R$ & $\begin{array}{c}\mathrm{G} \\
0.00\end{array}$ & $\begin{array}{c}\mathrm{C} \\
1.00\end{array}$ & $\begin{array}{c}\text { GG } \\
0.00\end{array}$ & $\begin{array}{c}\mathrm{GC} \\
0.00\end{array}$ & $\begin{array}{c}\mathrm{CC} \\
1.00\end{array}$ \\
\hline 19 & c. $274 \mathrm{C}>\mathrm{A}$ & Not in database & 34370848 & D)T & $\begin{array}{c}\mathrm{G} \\
0.00\end{array}$ & $\begin{array}{c}\mathrm{T} \\
1.00\end{array}$ & $\begin{array}{c}\mathrm{GG} \\
0.00\end{array}$ & $\begin{array}{c}\text { GT } \\
0.00\end{array}$ & $\begin{array}{c}\text { TT } \\
1.00\end{array}$ \\
\hline 20 & c. $276 \mathrm{C}>\mathrm{G}$ & Not in database & 34370846 & $P \backslash 1$ & $\begin{array}{c}\mathrm{G} \\
0.00\end{array}$ & $\begin{array}{c}\mathrm{C} \\
1.00\end{array}$ & $\begin{array}{c}\mathrm{GG} \\
0.00\end{array}$ & $\begin{array}{c}\mathrm{GC} \\
0.00\end{array}$ & $\begin{array}{c}\mathrm{CC} \\
1.00\end{array}$ \\
\hline 21 & c. $277 \mathrm{C}>\mathrm{A}$ & Not in database & 34370845 & $D \backslash T$ & $\begin{array}{c}\mathrm{G} \\
0.00\end{array}$ & $\begin{array}{c}\mathrm{T} \\
1.00\end{array}$ & $\begin{array}{c}\text { GG } \\
0.00\end{array}$ & $\begin{array}{c}\text { GT } \\
0.00\end{array}$ & $\begin{array}{c}\mathrm{TT} \\
1.00\end{array}$ \\
\hline 22 & c. $279 \mathrm{C}>\mathrm{T}$ & Not in database & 34370843 & $P \backslash 1$ & $\begin{array}{c}\mathrm{G} \\
0.00\end{array}$ & $\begin{array}{c}\mathrm{A} \\
1.00\end{array}$ & $\begin{array}{c}\text { GG } \\
0.00\end{array}$ & $\begin{array}{c}\text { GA } \\
0.00\end{array}$ & $\begin{array}{l}\mathrm{AA} \\
1.00\end{array}$ \\
\hline 23 & c. $281 \mathrm{C}>\mathrm{A}$ & Not in database & 34370841 & $\mathrm{~T} \backslash \mathrm{N}$ & $\begin{array}{c}\mathrm{G} \\
0.00\end{array}$ & $\begin{array}{c}\mathrm{T} \\
1.00\end{array}$ & $\begin{array}{c}\mathrm{GG} \\
0.00\end{array}$ & $\begin{array}{c}\text { GT } \\
0.00\end{array}$ & $\begin{array}{c}\text { TT } \\
1.00\end{array}$ \\
\hline 24 & c. $287 \mathrm{C}>\mathrm{A}$ & Not in database & 34370835 & $\mathrm{~A} \backslash \mathrm{D}$ & $\begin{array}{c}\mathrm{G} \\
0.00\end{array}$ & $\begin{array}{c}\mathrm{T} \\
1.00\end{array}$ & $\begin{array}{c}\mathrm{GG} \\
0.00\end{array}$ & $\begin{array}{c}\mathrm{GT} \\
0.00\end{array}$ & $\begin{array}{c}\mathrm{TT} \\
1.00\end{array}$ \\
\hline 25 & c. $325 \mathrm{~T}>\mathrm{C}$ & rs 599663516 & 34370797 & $\mathrm{~L}$ & $\begin{array}{c}\mathrm{A} \\
0.83\end{array}$ & $\begin{array}{c}\mathrm{G} \\
0.17\end{array}$ & $\begin{array}{c}\text { AA } \\
0.67\end{array}$ & $\begin{array}{c}\mathrm{AG} \\
0.33\end{array}$ & $\begin{array}{c}\mathrm{GG} \\
0.00\end{array}$ \\
\hline 26 & c. $483 \mathrm{C}>\mathrm{T}$ & Not in database & 34370639 & A & $\begin{array}{c}\mathrm{G} \\
0.00\end{array}$ & $\begin{array}{c}\mathrm{A} \\
1.00\end{array}$ & $\begin{array}{c}\mathrm{GG} \\
0.00\end{array}$ & $\begin{array}{c}\text { GA } \\
0.00\end{array}$ & $\begin{array}{l}\text { AA } \\
1.00\end{array}$ \\
\hline
\end{tabular}


Associations between newly discovered polymorphisms of the Myodl gene and body parameters ....

Table 2. The MyoD1 gene haplotypes identified in Stavropol sheep breed. Homozygous mutant genotype is highlighted in black, the heterozygous - in gray, and the homozygous wild-type genotype - in white

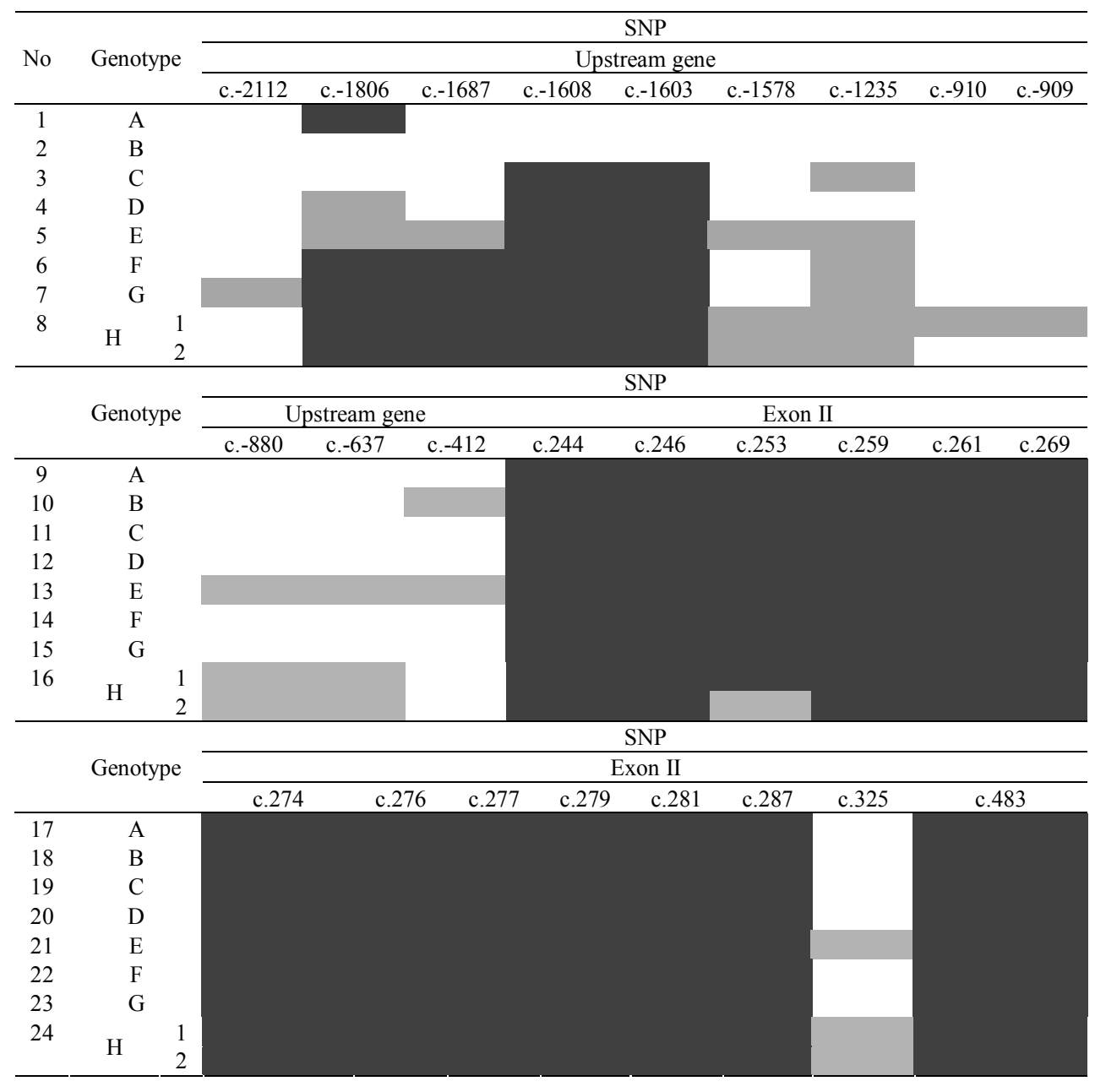

found SNPs and they are mainly located in the 5 ' flanking region, with the exception of SNP c.325T $>$ C located in exon 2.

The SNPs having both the heterozygous and mutant homozygous forms are found in $19 \%$ of cases and they are also located in the non-coding region of the gene. Substitutions detected in second exon are found in all tested animals only in homozygous form and constitute $46 \%$ of the total number of identified SNPs. From all detected SNPs, $42 \%$ led to a change of the encoded amino acids.

Among the detected mutations in the Stavropol breed transversions prevailed $(54 \%)$. The highest frequency of mutant alleles among animals examined were detected for SNPs c. $244 \mathrm{C}>\mathrm{T}$, c. $246 \mathrm{G}>\mathrm{T}$, 
$\begin{array}{lll}\text { c. } 253 \mathrm{G}>\mathrm{T}, & \text { c. } 259 \mathrm{G}>\mathrm{C}, & \text { c. } 261 \mathrm{C}>\mathrm{T}, \\ \text { c. } 269 \mathrm{C}>\mathrm{G}, & \text { c. } 274 \mathrm{C}>\mathrm{A}, & \text { c. } 276 \mathrm{C}>\mathrm{G}, \\ \text { c. } 277 \mathrm{C}>\mathrm{A}, & \text { c. } 279 \mathrm{C}>\mathrm{T}, & \text { c } .281 \mathrm{C}>\mathrm{A}, \\ \text { c. } 287 \mathrm{C}>\mathrm{A}, & \text { c. } 483 \mathrm{C}>\mathrm{T}, \text { c. } 325 \mathrm{~T}>\mathrm{C} . \text { All of }\end{array}$ c. $287 \mathrm{C}>\mathrm{A}$, c. $483 \mathrm{C}>\mathrm{T}, \mathrm{c} .325 \mathrm{~T}>\mathrm{C}$. All of
them were located in the second exon. They were presented in the homozygous mutant variants, except for c.325T $>\mathrm{C}$ replacement. It was found in the heterozygous form. Frequencies of mutant alleles of SNPs c. $-2112 \mathrm{C}>\mathrm{G}$, c.-910G $>$ T, c. $-909 \mathrm{G}>\mathrm{T}$ were rare. They were found in less than $2 \%$ of rams. Replacements c. $-1578 \mathrm{G}>\mathrm{A}$, c. $-880 \mathrm{G}>\mathrm{A}$, c. $-637 \mathrm{C}>\mathrm{T}$ and c. $325 \mathrm{~T}>\mathrm{C}$ were identified in the Stavropol breed only together, and only in the heterozygous form.

Nine out of the ten previously described mutations were in 5 ' flanking region and one $(\mathrm{c} .325 \mathrm{~T}>\mathrm{C})$ was located in the second exon. The SNPs c.- $1608 \mathrm{C}>\mathrm{T}$, c.$1603 \mathrm{G}>\mathrm{T}$, c. $-1578 \mathrm{G}>\mathrm{A}$, detected for the first time, were located in the 5' flanking region. In the second exon, c. $244 \mathrm{C}>\mathrm{T}$, c. $246 \mathrm{G}>\mathrm{T}, \quad$ c. $253 \mathrm{G}>\mathrm{T}, \quad$ c. $259 \mathrm{G}>\mathrm{C}$, c. $261 \mathrm{C}>\mathrm{T}, \quad$ c. $269 \mathrm{C}>\mathrm{G}, \quad$ c. $274 \mathrm{C}>\mathrm{A}$, c. $276 \mathrm{C}>\mathrm{G}, \quad$ c. $277 \mathrm{C}>\mathrm{A}, \quad$ c. $279 \mathrm{C}>\mathrm{T}$, c. $281 \mathrm{C}>\mathrm{A}$, c. $287 \mathrm{C}>\mathrm{A}$ and c. $483 \mathrm{C}>\mathrm{T}$, also detected the first time in sheep, were found out.

The SNPs c.325T $>$ A and c. $483 \mathrm{C}>\mathrm{T}$ are synonymous. Twelve SNPs led to amino acid replacements. Some of nonsynonymous SNP's were located within one triplet. In the MyoD1 gene four modified triplets were found. Inside one of the triplet the following pairs of replacements have occurred: c. $244 \mathrm{C}>\mathrm{T}$ and c. $246 \mathrm{G}>\mathrm{T}$; c. $259 \mathrm{G}>\mathrm{C}$ and c. $261 \mathrm{C}>\mathrm{T}$; c. $274 \mathrm{C}>\mathrm{A}$ and c. $276 \mathrm{C}>\mathrm{G} ;$ c $.277 \mathrm{C}>\mathrm{A}$ and c. $279 \mathrm{C}>\mathrm{T}$.

From the combination of mutations, the animals were divided into eight main groups (A-H) and two subgroups within the group $\mathrm{H}$ (Table 2). The phylogenetic tree of detected genotypes is shown on Fig. 1. Haplotypes A and B had the least replacements and were found in $7 \%$ of the animals. The greatest numbers of SNPs had haplotypes found in $27 \%$ of animals in groups $\mathrm{H}$ and $\mathrm{E}$, identified in $7 \%$ of the animals. Haplotypes C, D, G had from 16 to 19 SNPs. The most common haplotype was $\mathrm{F}$, detected in $33 \%$ of the rams.

Sequencing of MyoD1 gene in Stavropol breed allowed to reconstruct the amino acid sequence of the encoded protein. Twelve out of twenty six found replacements lead to changes in the amino acid composition of protein. Structure of encoded MyoD1 peptide in Stavropol breed differed from reference MyoD1 sequence by presence of cysteine in positions 82 and 85 , arginine in positions 87

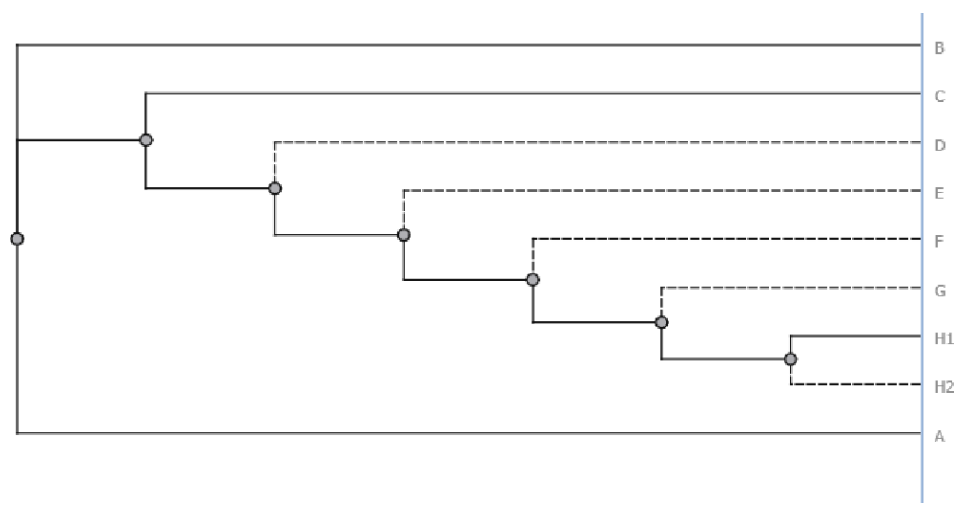

Fig. 1. Phylogenetic tree of detected haplotypes in Stavropol sheep. 


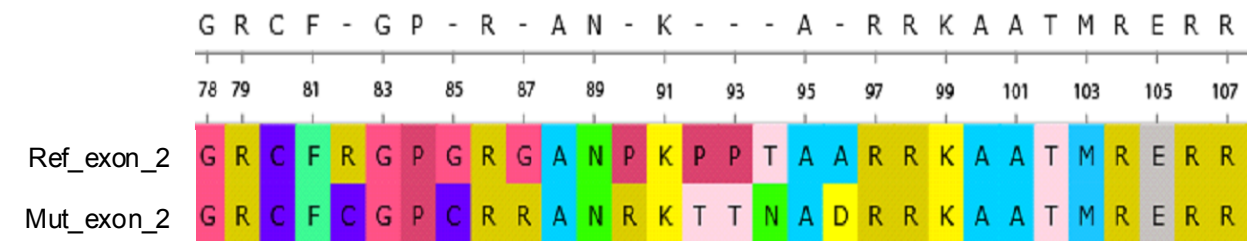

Fig. 2. Amino acids chains of the Myod1 protein in Stavropol sheep breed and reference (www. uniprot.org, 2016).

and 90 , threonine at positions 92 and 93 , asparagine in position 94, an aspartic acid in position 96 (Fig. 2).

The impact of replacements c.-1578, c. -880 , c. -637, c. 325 and c. -1235 on the ram's body parameters was studied to assess the possibility of using them as genetic markers in selection (Table 3). The complex of the four first SNPs are of interest to research because these replacements occurred only together in Stavropol sheep breed, indicating their linked inheritance. In addition, one of the replacements (c.325) was in the coding region of exon II. SNP c.-1235 occurred in a larger number of animals in the group than the previous four replacements. Heterozygous rams did not exhibit any significant difference in live weight with wildtype homozygotes. However, the chest girth, metacarpal girth and loin width in heterozygous rams was higher than in homozygotes. The study of described SNPs influence on the lifetime body parameters of rams showed almost no significant correlation between their presence and the size of the animals. Therefore, the use of SNP's c.-1578, c.-880, c.-637, c. 325 and c.-1235 as a genetic marker in the selection of Stavropol breed of sheep is not allowed.

Unfortunately, we couldn't conduct a study on correlation between SNP's, accompanied by the replacement of amino acids in the peptide chain and body pa- rameters. All these mutations in Stavropol were present only in the homozygous mutant variant. Therefore, within-breed comparison with individuals carrying the wild haplotype was not possible.

Perhaps SNPs c.-910 and c.-909 were associated with greater body parameter values, as they were found in animals with higher weight.

\section{DISCUSSION}

In our study, $M y o D l$ gene structure was investigated for the first time and assessment of the identified polymorphisms in the body parameters in rams of Stavropol sheep breed was done. Genotyping of Russian sheep breeds has not been done earlier and there is no information on MyoD1 gene structure. There are also no data of the effect of $M y o D 1$ gene structure on sheep body parameters in other countries.

The study of $M y o D l$ gene structure identified regions of the DNA chain, which differed in the number of single nucleotide replacements. The greatest number of SNPs contained Exon II, the least variable was 5 ' flanking region.

Most SNPs found in the second exon are in the homozygous mutant variant. The exception was SNP c.325T $>$ C, which was in the heterozygous form. Apparently, the carriers of mutant alleles differed by best qualities in the selection of pairs for 
V. Trukhachev, V. Skripkin, E. Telegina, O. Yatsyk, N. Golovanova \& A. Krivoruchko

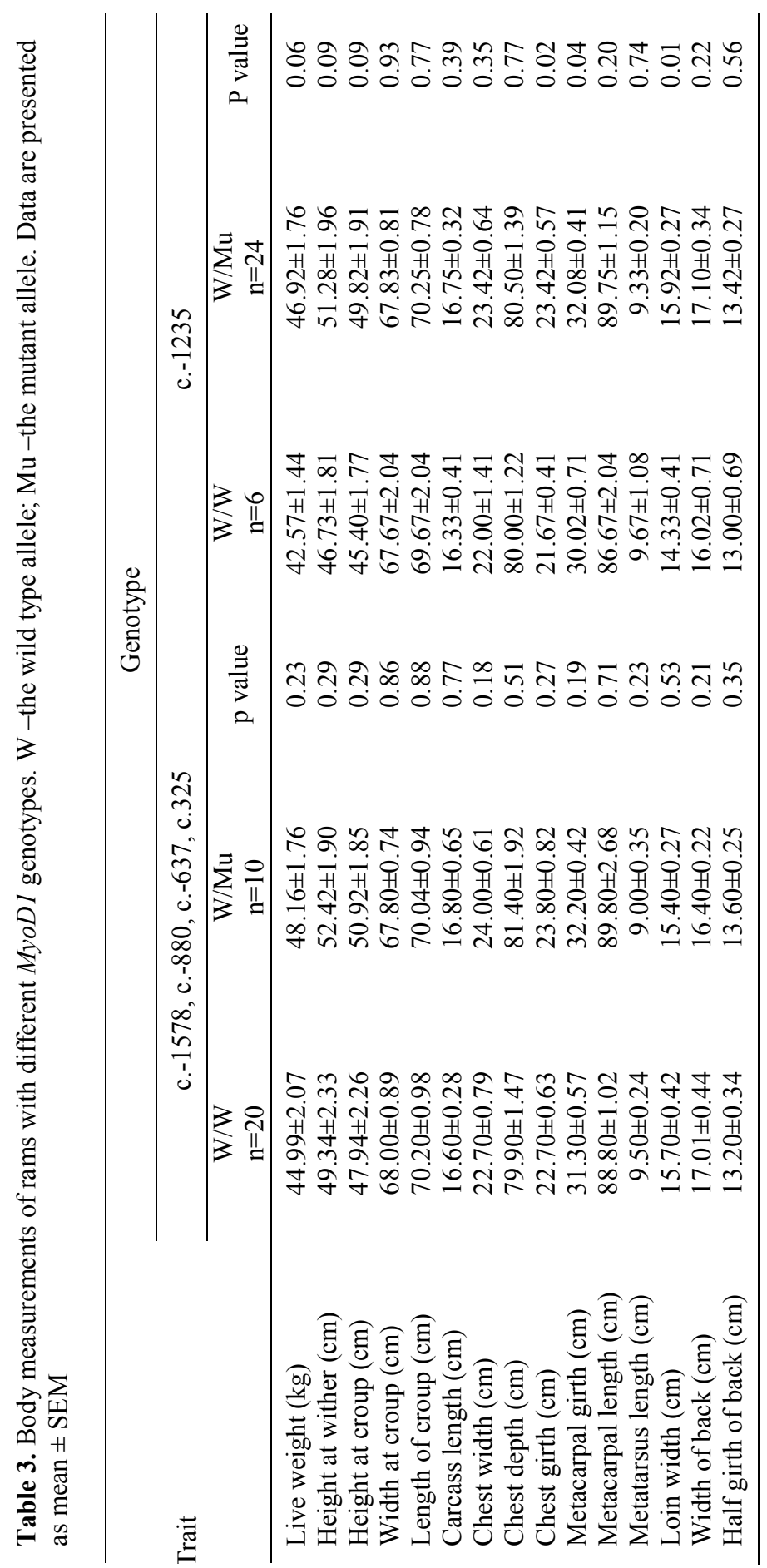

BJVM, 21, No 1 
crossing. That led to the consolidation of mutations in Stavropol breed in homozygous form.

Four SNPs: c. $-1578 \mathrm{G}>\mathrm{A}$, c. $-880 \mathrm{G}>\mathrm{A}$, c. $-637 \mathrm{C}>\mathrm{T}$ and c.325T $>\mathrm{C}$ in Stavropol breed of sheep were found in the heterozygous form and only together, which may indicate their linked inheritance. Three of them (c. $-1578 \mathrm{G}>$ A, c. $-880 \mathrm{G}>\mathrm{A}$, c. $-637 \mathrm{C}>\mathrm{T})$ were identified for the first time.

In Ensembl database we found information about the frequency of occurrence of single nucleotide replacements in MyoD1 gene in Iranian and Moroccan breeds of sheep, which were close to Stavropol breed of sheep. In Stavropol rams the SNP c. $-2112 \mathrm{C}>\mathrm{G}$ in the flanking region occurs with a frequency of $3 \%$, which is lower than the Iranian (10\%) and Moroccan (19\%). SNPs c. $-910 \mathrm{G}>\mathrm{T}$, c.909G $>$ T in Stavropol and Iranian breeds are found with the same frequency $(10 \%)$, which is by $5 \%$ higher than that in the Moroccan. The frequency of replacement c. $637 \mathrm{C}>\mathrm{T}$ in Moroccan sheep is by $12 \%$ lower than in Stavropol and Iranian breeds $(17 \%)$. c. $-1235 \mathrm{G}>\mathrm{C}$ replacement in Moroccan breed occurs with a frequency of $32 \%$, which is lower than that of the Stavropol (40\%) and Iranian (37\%) breeds. The replacement c. $-880 \mathrm{G}>\mathrm{A}$ with a frequency of $17 \%$ is higher than in Iranian $(8 \%)$ and Moroccan (3\%) breeds. The SNP c.325T $>$ C located in exon II of Stavropol breed has a same frequency of occurrence as those of Moroccan and Iranian breeds (Anonymous, 2016).

This indicates the need for further research of encoded peptide features. The linked pairs of SNP's inside coding nucleotide triplets are c.-244C $\mathrm{T}$ and c.$246 \mathrm{G}>\mathrm{T}$; c. $-259 \mathrm{G}>\mathrm{C}$ and c. $-261 \mathrm{C}>\mathrm{T}$; c. $274 \mathrm{C}>\mathrm{A}$ and c. $-276 \mathrm{C}>\mathrm{G}$; c. $-277 \mathrm{C}>\mathrm{A}$ and c. $-279 \mathrm{C}>\mathrm{T}$, which are accompanied with non-synonymous amino acid changes in MyoD1 protein. As these SNP have been detected for the first time, this provides evidence for the unique structure of the MyoD1 protein in the Stavropol breed. Replacements c.325T $>\mathrm{C}$ and c. $483 \mathrm{C}>\mathrm{T}$ in exon II are associated with synonymous amino acid replacements, but may be related to functional characteristics of the encoded peptide. Previously, some cases of SNP's present in coding regions of proteins with identical amino acid sequence, which differ in functional and structural parameters of proteins, were described (Komar, 2007).

In all investigated animals, we found a unique structure of the $M y o D 1$ gene. It is accompanied by changes in the amino acid composition of the encoded protein in Stavropol sheep breed, which had not been detected in any other sheep breeds. However, in our study we were unable to study its influence on meat production. In this case one way to detect the influence of gene structure on meat quality is a breeding hybrid with another breed, which will carry heterozygous haplotype of these SNP's. Study of mass indexes and body size of the obtained heterozygous offspring compared with the native wild haplotype allows detecting the effect of the unique structure of MyoDl gene in Stavropol sheep breed.

In our study, SNPs c.-910 and c.-909 occurred in a very small number of animals, which did not allow making definitive conclusions. In the future, their influence on the lifetime and slaughter yield indicators of sheep productivity will be further investigated in detail.

\section{CONCLUSION}

The study shows a significant difference of MyoDl gene in Stavropol breed of 
sheep from the reference gene variant, the changes relating to the coding regions. During our work, we found 26 SNPs, 16 of these were discovered for the first time and were not entered into dbSNP NCBI. The study of the effect of described SNPs on the body parameters of rams showed the absence of correlation between their presence and the size of the animals. It is not possible to recommend the use of SNP c. -1578 , c. -880 , c. -637 , c. 325 and c. -1235 as a genetic marker in the selection of Stavropol breed of sheep.

\section{ACKNOWLEDGEMENTS}

This project was funded by the Ministry of Agriculture of the Russian Federation (agreement on the procedure and conditions for granting subsidies to financial security the state order for the provision of public services (works) by December 30, 2013 № 3119/13).

\section{REFERENCES}

Aboneev, V. V., Y. D. Quito, I. G. Serdyukov \& M. Y. Sannikov, 2011. Stavropol breed is 60 years old. Sheep, Goats, Wool Business, 4, 1-3 (RU).

Anonymous, 2016. http://www.ensembl.org/ Ovis_aries/ Transcript/Summary? $\mathrm{db}=$ core;

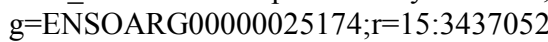
8-34371122;t=ENSOART00000027076; $\mathrm{v}=\mathrm{ss} 1139613360 ; \mathrm{vdb}=$ variation; $\mathrm{vf}=26978$ 378 (Date last accessed 22 December 2016).

Asakura, A., H. Hirai, B. Kablar, S. Morita, J. Ishibashi, B. A. Piras, A. J. Christ, M. Verma, K. A. Vineretsky \& M. A. Rudnicki, 2007. Increased survival of muscle stem cells lacking the MyoD gene after transplantation into regenerating skeletal muscle. Proceedings of the National Academy of Sciences of the United States of America, 104, 16552-16557.

Buckingham, M., 1992. Making muscle in animals. Trends in Genetics, 8, 144-149
Busanello, A., C. Battistelli, M. Carbone, C. Mostocotto \& R. Maione, 2012. MyoD regulates p57kip2 expression by interacting with a distant cis-element and modifying a higher order chromatin structure. Nucleic Acids Research, 40, 8266-8275.

Bhuiyan, M. S. A., N. K. Kim, Y. M. Cho, D. Yoon, K. S. Kim, J. T. Jeon \& J. H. Lee, 2009. Identification of SNPs in MYOD gene family and their associations with carcass traits in cattle. Livestock Science, 126, 292-297.

Davis, R. L., H. Weintraub \& A. B Lassar, 1987. Expression of a single transfected cDNA converts fibroblasts to myoblasts. Cell, 51, 987-1000.

Deng, B., J. Wen, Y. Ding, Q. Gao, H. Huang, Z. Ran, Y. Qian, J. Peng \& S. Jiang, 2012. Functional analysis of pig myostatin gene promoter with some adipogenesis and myogenesis-related factors. Molecular Cell Biochemistry, 363, 291-299.

Dmytryk, I. I. \& E. G. Ovchinnikova, 2013. Assessment of meat qualities of young growth of sheep of the Stavropol breed on a complex of properties. Veterinary $\mathrm{Pa}$ thology, 1, 43.

Du, R., X. An, Y. Chen \& J. Qin, 2007. Functional analysis of the Myostatin gene promoter in sheep. Science China Serial $C$ Life Sciences, 50, 648-654.

Gan, S. Q., Z. Du, S. R. Liu, Y. L. Yang, M. Shen, X. H. Wang, J. L. Yin, X. X. Hu, J. Fei, J. J. Fan, J. H. Wang, Q. H. He, Y. S. Zhang \& N. Li, 2008. Association of SNP Haplotypes at the Myostatin Gene with Muscular Hypertrophy in Sheep. AsianAustralasian Journal of Animal Sciences, 21, 928-935.

Gerber, A., T. R. Klesert, D. A. Bergstrom \& S. J. Tapscott, 1997. Two domains of MyoD mediate transcriptional activation of genes in repressive chromatin a mechanism for lineage determination in myogenesis. Genes Development, 11, 436-450.

Hagen, I. J., A. Zadissa, J. C. McEwan, B. A. Veenvliet, S. M. Hickey, N. G. Cullen, C. A. Morris \& T. Wilson, 2005. Molecular 
and bioinformatic strategies for gene discovery for meat traits: A reverse genetics approach. Australian Journal of Experimental Agriculture, 45, 801-807.

Huynen, L., J. Bass, R. C. Gardner \& A. R. Bellamy, 1992. Nucleotide sequence of the sheep MyoD1 gene. Nucleic Acids Research, 20, 374 .

Kapelanski, W., S. Grajewska, J. Kuryl, M. Bocian, J. Wyszyńska-Koko \& P. Urbański, 2005. Polymorphism in coding and non coding regions of the MYOD gene family and meat quality in pigs. Folia Biologica, 53, 45-49.

Klosowska, D., J. Kuryl, G. ElminowskaWenda \& W. Kapelanski, 2004. A relationship between the PCR-RFLP polymorphism in porcine MYOG, MYOD1 and $M Y F 5$ genes and microstructural characteristics of $\mathrm{m}$. longissimus lumborum in Pietrain. Czech Journal of Animal Sciences, 49, 99-107.

Komar, A. A., 2007. SNPs, silent but not invisible. Science, 315, 466-467.

Kuryl, J., W. Kapelañski, D. Cieoelak, M. Pierzchala \& S. Grajewska, 2002. Are polymorphisms in non-coding regions of porcine MyoD genes suitable for predicting meat and fat deposition in the carcass. Animal Sciences Papers and Reports, 20, 245-254.

Liu, M., J, Peng, D. Q. Xu \& R. Zheng, 2008. Association of MYF5 and MYOD1 gene polymorphisms and meat quality traits in Large White $\times$ Meishan F2 pig populations. Biochemical Genetics, 46, 720-732.

Lobo, A. M. B. O., S. E. F. Guimarães, S. R. Paiva, F. F Cardoso, F. F. Silva, G. A. Fernandes \& R. N. B. Lobo, 2012. Differentially transcribed genes in skeletal muscle of lambs. Livestock Science, 150, 3141.

Megeney, L. A., B. Kablar, K. Garrett, J. E. Anderson \& M. A. Rudnicki, 1996. MyoD is required for myogenic stem cell function in adult skeletal muscle. Genes Development, 10, 1173-1183.
Muroya, S., I. Nakajima \& K. Chikuni, 2002. Related expression of MyoD and Myf5 with myosin heavy chain isoform types in bovine adult skeletal muscles. Zoological Science, 19, 755-761.

Murre, C., P. S. McCaw, H. Vaessin, M. Caudy, L. Y. Jan, Y. N. Jan, C. V. Cabrera, J. N. Buskin, S. D. Hauschka, A. B. Lassar, H. Weintraub \& D. Baltimore, 1989. Interactions between heterologous helix-loop-helix proteins generate complexes that bind specifically to a common DNA sequence. Cell, 58, 537-544.

Pan, Y. C., X. W. Wang, H. F. Teng, Y. J. Wu, H. C. Chang \& S. L. Chen, 2015. Wnt3a signal pathways activate MyoD expression by targeting cis-elements inside and outside its distal enhancer. Bioscience Reports, 35, e00180.

Tapscott, S., R. L. Davis, M. J. Thayer, P. F. Cheng, H. Weintraub \& A. B. Lassar, 1988. MyoD1 a nuclear phosphoprotein requiring a myc homology region to convert fibroblasts to myoblasts. Science, 242, 405-411.

Ujan, J. A., L. S. Zan, H. B. Wang, S. A. Ujan, C. Adoligbe, H. C. Wang \& S. F. Biao, 2011. Lack of an association between a single nucleotide polymorphism in the bovine myogenic determination 1 (MyoD1) gene and meat quality traits in indigenous Chinese cattle breeds. Genetics and Molecular Research, 10, 2213-2222.

Vandromme, M., J. C. Cavadore, A. Bonnieu, A. Froeschle, N. Lamb \& A Fernandez, 1995. Two nuclear localization signals present in the basic-helix 1 domains of MyoD promote its active nuclear translocation and can function independently. Proceeding of the National Academy of Sciences, 92, 4646-4650

Verner, J., P. Humpolicek, \& A. Knoll, 2007. Impact of MYOD family genes on pork traits in Large White and Landrace pigs. Journal of Animal Breeding and Genetic, 124, 81-85.

Weintraub, H., V. J. Dwarki, I. Verma, R. Davis, S. Hollenberg, L. Snider, A. Lassar 
\& S. J. Tapscott, 1991. Muscle specific transcriptional activation by MyoD. Genes Development, 5, 1377-1386.

Yang, Z. Q., Y. Qing, Q. Zhu, X. L. Zhao, Y. Wang, D. Y. Li, Y. P. Liu \& H. D. Yin, 2015. Genetic effects of polymorphisms in myogenic regulatory factors on chicken muscle fiber traits. Asian-Australian Journal of Animal Sciences, 28, 782-787.

Zhang, Y., X. Tan, P. J. Zhang \& Y. Xu, 2006. Characterisation of muscle-regulatory gene, MyoD, from flounder (Paralichthys olivaceus) and analysis of its expression patterns during embryogenesis. Marine Biotechnology, 8, 139-148.
Paper received 13.10.2016; accepted for publication 25.11.2016

\section{Correspondence:}

Dr. Alexander Krivoruchko Faculty of Veterinary Medicine Stavropol State Agrarian University Stavropol, Russian Federation 355017, Zootehnichesky, 12

Phone: +79188814327

Fax: +78652286738

e-mail: rcvm@yandex.ru 